\title{
Perbedaan Profil Abses Hati Pyogenic dengan Amoebic pada Pasien Abses Hati Rawat Inap di RSUD Dr Soetomo Tahun 2016-2019
}

\author{
Annisya Dinda Paramitha ${ }^{1}$, Ulfa Kholili ${ }^{2}$, Bagus Setyoboedi ${ }^{3}$
}

\begin{abstract}
Abstrak
Abses hati dibagi menjadi dua berdasarkan penyebab, yaitu bakteri pyogenik dan amoebik. Abses hati yang terjadi pada Dr. Soetomo masih belum diketahui, tetapi protozoa atau bakteri yang menyebabkan abses hati ditemukan banyak di Indonesia. Tujuan: Menentukan perbedaan profil klinis antara pasien dengan abses hati amoebik dan pyogenik di RSUD Dr. Soetomo pada periode 2016 sampai 2019. Metode: Studi ini adalah analitik observasional menggunakan pendekatan cross-sectional pada rekam medis, dengan kriteria inklusi tes seroamoeba dan USG. Data dianalisis menggunakan uji Chi-square untuk skala nominal, t-test dan Man-Whitney untuk skala interval. Hasil: Ada 58 pasien dengan abses hati, masing-masing terdiri dari 29 pasien pada kedua jenis abses hati. Abses hati terjadi lebih dari $85 \%$ pada pria dengan usia rerata 42 hingga 45 tahun. Manifestasi klinis yang paling umum adalah nyeri RUQ (Kuadran Kanan Atas) (93,1\%), hepatomegali (70\%), dan demam (69\%). Hasil pemeriksaan USG adalah abses tunggal di lobus kanan. Tinjauan terapi menggunakan drainase perkutan lebih dari operasi. Komplikasi yang paling umum adalah efusi pleura $(37,9 \%)$ dan sepsis (34,5\%). Kematian hanya terjadi pada abses hati pyogenik sebesar 13,8\%, sedangkan pada amoebik 0\%. Rerata lama durasi abses hati (LOS) adalah 15 (sekitar 7 hari). Simpulan: Terdapat perbedaan karakteristik, gambaran klinis, dan angka kematian antara pasien abses hati amoebik dan pyogenik, dan terbukti secara statistika pada mortalitas.
\end{abstract}

Kata kunci: abses hati amoebic, abses hati pyogenic, rawat inap

\section{Abstract}

Liver abscess is divided into 2 based on its cause, namely pyogenic bacteria and amoebic. Liver abscesses in Dr. Soetomo were still unknown, but the protozoa or bacteria that cause liver abscesses are abundantly found in Indonesia. Objectives: To determined the differences in the clinical profile of patients with amoebic and pyogenic liver abscesses in Dr. Soetomo Hospital in 2016 until 2019. Methods: This study was an observational analytic using crosssectional approach on medical records, with the inclusion criteria of seroamoeba tests and USG. The data were analyzed using by Chi-square test. The test for the nominal scale was t-test and Man-Whitney was used for interval scale. Results: There were 58 patients with liver abscesses; each consisted of 29 patients in both liver abscess types. Liver abscess occurred more than $85 \%$ in men with an average age of 42 to 45 years. The most common clinical manifestations were RUQ (Right Upper Quadrant) pain (93.1\%), hepatomegaly (70\%), and fever (69\%). The result of a USG examination was single abscesses in the right lobe. The overview of therapy used percutaneous drainage more than surgery. The most common complications were pleural effusion (37.9\%) and sepsis (34.5\%). Mortality only occurred in pyogenic liver abscess by $13.8 \%$, while in amoebic was $0 \%$. Finally, the average liver abscess duration length of stay (LOS) was 15 (approx. 7 days). Conclusion: There were differences in characteristics, clinical features, and mortality rates between amoebic and pyogenic liver abscess patients, which have been proven statistically in mortality

Keywords: amoebic liver abscess, pyogenic liver aabscess, hospital

Affiliasi penulis: ${ }^{1} \mathrm{~S} 1$ Fakultas Kedokteran, Universitas Airlangga, Surabaya, Indonesia. ${ }^{2}$ RSUD Dr. Soetomo, Surabaya, Indonesia.
${ }^{3}$ Departemen IImu Kesehatan Anak, Fakultas Kedokteran, Universitas Airlangga, Surabaya, Indonesia. 
Korespondensi : Annisya Dinda Paramitha Jl. Mayjen Prof. Dr. Moestopo No. 47 Surabaya 60131, Indonesia. an.nisya16@ymail.com Telp: 08113442008

\section{PENDAHULUAN}

Abses hati adalah penyakit yang ada sejak zaman dahulu yang sering berhubungan dengan akut appendicitis atau infeksi intra-abdominal. ${ }^{1}$ Menurut Su et al (2010), lebih banyak pasien laki-laki (63.5\%) yang terkena abses hati dari pada perempuan (36.5\%). Pada laki- laki cenderung berusia lebih muda untuk terkena abses hati dari pada perempuan. ${ }^{2}$ Angka mortalitas abses hati pyogenic sangat tinggi bisa mencapai hampir $40 \%$ karena pada saat hingga tahun 1980, itu belum diketahui bahwa antibiotik dapat menjadi pilihan terapi. ${ }^{3}$ Dengan adanya antibiotika, maka angka mortalitas dapat diketahui hingga kurang dari 10\%. Angka kematian yang mencapai $30 \%$ biasanya menandakan keberadaan komplikasi seperti ruptur abses. Jika pasien memiliki faktor komorbid yang mendukung untuk terjadinya prognosis yang lebih buruk maka akan menaikkan mortality rate hingga tiga kali lipat. ${ }^{4}$

Abses hati pyogenic terjadi karena adanya infeksi oleh bakteri aerob maupun anaerob yang mengarah ke descending infection. Bakteri tersebut masuk melalui sirkulasi sistemik, seperti sistem portal, yang akhirnya menyebabkan rusaknya sel pada jaringan hati. Selain sirkulasi sistemik, abses hati pyogenic juga dapat disebabkan oleh obstruksi dari saluran empedu. Hal ini menyebabkan kenaikan marker laboratorium, seperti bilirubin, SGOT dan SGPT, serta didapatkan penurunan $\mathrm{Hb}$ dan albumin pada pasien abses hati pyogenic. Kerusakan yang disebabkan oleh bakteri kebanyakan multiple pada lobus kanan abses hati. ${ }^{5}$ Pada abses hati yang disebabkan oleh bakteri pyogenic, lebih banyak terjadi di Amerika dengan angka kejadian 2.3 dari 100.000 populasi yang akan meningkat seiring naiknya faktor usia. ${ }^{6}$ Abses hati pyogenic juga sering terjadi pada Asia barat. Pada Asia barat $84 \%$ pasien terdiagnosis sebagai abses hati karena bakteri pyogenic, yaitu Klebsiella pneumoniae. ${ }^{7}$ Abses hati karena bakteri pyogenic mempunyai prevalensi sebesar $48 \%$ terhadap seluruh jenis abses pada jaringan. ${ }^{8}$
Abses hati amoebic adalah manifestasi ekstraintestinal terbanyak pada infeksi dari protozoa Entamoeba histolytica. ${ }^{9}$ Parasit ini masuk melalui jalur ascending dari GI Tract atau melalui vena portal. Setelah masuk parasit ini mengeluarkan enzim proteolitik yang akhirnya dapat meningkatkan kadar leukosit dengan sangat tinggi. Karena memasuki lewat vena portal maka lobus yang terkena lebih banyak pada lobus kanan dengan karakteristik single dengan ukuran lebih besar. ${ }^{5}$ Keberadaan protozoa Entamoeba histolytica paling banyak terdapat di Asia, dikarenakan banyak negara berkembang dengan status ekonomi rendah. $^{10} \mathrm{Di}$ Indonesia keberadaan Entamoeba histolytica sebesar 18\%-25\% dengan infeksi ekstra instestinal terbanyak adalah hepar. ${ }^{11}$

Abses hati yang terjadi di RSUD Dr. Soetomo masih belum diketahui angka kejadiannya, akan tetapi keberadaan protozoa atau bakteri penyebab abses hati banyak ditemukan di Indonesia. Penelitian ini diarahkan untuk menentukan perbedaan profil klinis dari pasien abses hati pyogenic dengan amoebic pada RSUD Dr. Soetomo pada tahun 2016-2019.

\section{METODE}

Penelitian ini merupakan studi analitik menggunakan pendekatan cross-sectional. Penelitian analitik mempunyai tujuan untuk menganalisis perbedaan profil klinis pasien abses hati pyogenic dan amoebic pada pasien rawat inap di RSUD Dr. Soetomo. Data yang diambil merupakan data sekunder yaitu rekam medis di RSUD Dr. Soetomo Surabaya dengan periode waktu dari Januari 2016Oktober 2019. Ethical clearance didapatkan tanggal 26 agustus 2019 dengan nomor 1453/KEPK/VII/2019 dari Komite Etik RSUD Dr. Soetomo Surabaya. Sampel yang diambil adalah pasien abses hati, dengan International Statistical Classification of Disease (ICD) K75.0, pada rawat inap RSUD Dr. Soetomo dengan kriteria inklusi berupa terdapat hasil pemeriksaan laboratorium berupa tes seroamoeba yang dapat menegakkan diagnosis jenis abses hati serta memiliki hasil pemeriksaan radiologik berupa USG (Ultrasonography) yang mendukung diagnosis abses hati. Jika tes seroamoeba yang didapat menunjukkan hasil positif maka akan dimasukkan 
dalam kelompok abses hati amoebic, apabila negatif maka masuk kedalam kelompok abses hati pyogenic.

Hasil pemeriksaan radiologic berupa USG yang digunakan sebagai data pada penlitian ini adalah hasil saat pertama kali masuk rumah sakit. Teknik pengambilan sampel yang dipakai adalah total sampling dengan jumlah 58 pasien yang terdiri dari 29 pasien abses hati amoebic dan 29 pasien abses hati pyogenic. Variabel bebas dari penelitian ini adalah abses hati amoebic dan pyogenic, sedangkan variabel terikat adalah karakteristik umum; umur, jenis kelamin, pendidikan, pekerjaan, riwayat penyakit dahulu, gambaran klinis berupa manifestasi klinis; demam, nyeri perut Right Upper Quadran, mual, muntah, hepatomegaly, ikterus, pemeriksaan laboratorium; $\mathrm{Hb}$, albumin, leukosit, bilirubin direk dan total, SGOT dan SGPT, natrium, kalium, klorida, pemeriksaan radiologis; ukuran, letak dan jumlah lesi abses, terapi farmakologis berupa metronidazole dan antibiotik, penggunaan drainase dan operasi, komplikasi yang dapat terjadi berupa; emphyema, efusi pleura, rupture abses/perforasi, sepsis, serta outcome yang terdiri dari mortalitas dan LOS (Length of Stay).

Data diambil di rumah sakit dan dilakukan pencatatan pada lembar pengambilan data pada jam kerja. Pengolahan data pada penelitian ini mempunyai 4 tahap yaitu editing, coding, entry, cleaning. Editing dilakukan untuk menyeleksi hasil data yang memenuhi ketentuan kriteria inklusi dan eksklusi sampel. Coding dilakukan untuk mempermudah analisa saat memakai computer agar proses berjalan lebih cepat. Lalu data di entry pada program analisa yang dipakai dan cleaning dilakukan untuk meminimalisir kesalahan yang terjadi pada pengolahan data. Pada karakteristik umum dan terapi data diolah secara deskriptif, sedangkan untuk variable gambaran klinis, komplikasi, dan outcome data diolah secara analitik. Setelah data diolah melalui 4 tahap tersebut, data akan dianalisis menggunakan program komputer dengan Uji Chiquare untuk skala nominal, sedangkan Uji t-test dan Man-Whitney untuk skala interval.
HASIL

Sampel dipilih berdasarkan kriteria inklusi dan eksklusi sehingga dari 143 populasi pasien abses hati pada rawat inap RSUD Dr. Soetomo dari Januari 2016 hingga Oktober 2019 didapatkan sampel berjumlah 58 pasien yang terdiri dari 2 kelompok yaitu amoebic (29 pasien) dan pyogenic (29 pasien). Karakteristik umum sampel didapat adalah jenis kelamin, umur, pendidikan, pekerjaan, riwayat penyakit sebelum. Karakteristik yang akan dianalisis menggunakan metode Chi-square adalah jenis kelamin, umur, dan riwayat penyakit sebelum, sedangkan untuk pendidikan dan pekerjaan akan ditampilkan secara deskriptif saja. Pada kedua jenis abses hati didapatkan bahwa lebih banyak pasien laki-laki daripada perempuan dimana abses hati amoebic terdiri dari $89,6 \%$ laki-laki dan abses hati pyogenic menunjukkan angka $86,2 \%$. Reata umur didapatkan lebih tua pada abses hati pyogenic (44,5 \pm 18 tahun) daripada abses hati amoebic (41,6 \pm 16 tahun). Keberadaan Riwayat penyakit dahulu juga didapatkan lebih banyak pada abses hati pyogenic dengan angka $62,1 \%$ daripada abses hati amoebic yang hanya sekitar $44,8 \%$. Hasil analisis pada ketiga parameter tersebut menghasilkan $p>0,05$ ( $p$; jenis kelamin: 0,687, umur: 0,516, Riwayat penyakit dahulu: 0,056) sehingga didapatkan tidak terdapat perbedaan signifikan terhadap parameter tersebut. Pada pendidikan paling banyak ditemukan pada tingkat lulus SLTA sedangkan untuk pekerjaan paling banyak adalah pegawai swasta pada kedua jenis abses.

Manifestasi klinis yang diteliti berupa gejala, pemeriksaan laboratorium, dan pemeriksaan USG. Gejala yang paling banyak ditemukan pada kedua abses adalah nyeri Right Upper Quadran mencapai $93,1 \%$, setelah itu $70,6 \%$ pasien mengalami hepatomegaly dan $69 \%$ mengalami demam. Beberapa keluhan lain yang jarang ditemukan adalah ikterus $(56,8 \%)$ dan mual muntah. Semua dianalisis menggunakan Chi-square dan tidak ditemukan perbedaan signifikan pada gejala tersebut karena 
$p>0,05$. Pemeriksaan laboratorium yang dilampirkan dalam bentuk mean/median $\pm \mathrm{SD}$ terdiri dari; $\mathrm{Hb}$, leukosit, albumin, bilirubin total dan direk, SGOT dan SGPT, natrium, kalium, klorida.

Tabel 1. Tabel karakteristik umum pada pasien abses hati

\begin{tabular}{|c|c|c|c|}
\hline \multirow[t]{2}{*}{ Parameter } & \multicolumn{2}{|c|}{ Jenis abses } & \multirow[t]{2}{*}{$p$} \\
\hline & $\begin{array}{l}\text { Amoebic } \\
(\%) n=29\end{array}$ & $\begin{array}{l}\text { Pyogenic } \\
(\%) n=29\end{array}$ & \\
\hline Jenis Kelamin & & & 0,687 \\
\hline -Laki-laki & $89,6 \%$ & $86,2 \%$ & \\
\hline -Perempuan & $10,4 \%$ & $13,8 \%$ & \\
\hline Umur (rerata $\pm S D)$ & $41,6 \pm 16$ & $44,5 \pm 18$ & 0,516 \\
\hline Pendidikan & & & - \\
\hline -Tamat SD & $3,4 \%$ & $10,3 \%$ & \\
\hline -Tidak Tamat SD & $7 \%$ & $3,4 \%$ & \\
\hline -Tamat SLTP & $10,3 \%$ & $7 \%$ & \\
\hline -Tamat SLTA & $75,9 \%$ & $55,2 \%$ & \\
\hline -Tamat D3 & $0 \%$ & $3,4 \%$ & \\
\hline -Lain-lain & $3,4 \%$ & $20,7 \%$ & \\
\hline Pekerjaan & & & - \\
\hline -Pegawai swasta & $55,1 \%$ & $44,8 \%$ & \\
\hline -Pegawai negeri & $13,7 \%$ & $10,3 \%$ & \\
\hline -wiraswata & $7 \%$ & $3,4 \%$ & \\
\hline -Petani & $7 \%$ & $7 \%$ & \\
\hline -Pelajar & $3,4 \%$ & $3,4 \%$ & \\
\hline -Pedagang & $3,4 \%$ & $0 \%$ & \\
\hline -lbu rumah tangga & $3,4 \%$ & $7 \%$ & \\
\hline -Pensiun & $0 \%$ & $3,4 \%$ & \\
\hline -Lain-lain & $7 \%$ & $20,7 \%$ & \\
\hline $\begin{array}{l}\text { Riwayat Penyakit } \\
\text { Dahulu }\end{array}$ & $44,8 \%$ & $62,1 \%$ & 0,056 \\
\hline -Diabetes melitus & $8,1 \%$ & $16,7 \%$ & \\
\hline -Hipertensi & $15,3 \%$ & $16,7 \%$ & \\
\hline -Hiperkolesterol & $8,1 \%$ & $5,6 \%$ & \\
\hline -Merokok & $15,3 \%$ & $5,6 \%$ & \\
\hline -Alkohol & $23,4 \%$ & $11,1 \%$ & \\
\hline -Lain-lain & $30,7 \%$ & $44,4 \%$ & \\
\hline
\end{tabular}

Rerata $\mathrm{Hb}$ dari kedua jenis abses sama yaitu sekitar 10,56 $\pm 2,25$. Leukosit ditemukan lebih tinggi pada abses hati amoebic dengan 10,56 $\pm 2,25$ daripada pyogenic yaitu sekitar $16.971 \pm 6.816$, disamping itu albumin juga ditemukan lebih tinggi pada abses hati amoebic dengan rerata $2,9 \pm 0,53$ daripada pyogenic $(2,6 \pm 0,63)$. Pada bilirubin direk, total, SGOT, dan SGPT ditemukan nilai yang lebih tinggi pada abses hati pyogenic daripada amoebic. Median dari bilirubin direk dan total pada abses hati pyogenic berturut-turut adalah 2,85 dan 3,75, sedangkan pada abses hati amoebic adalah 1,48 dan 2,98. Median dari SGOT dan SGPT pada abses hati pyogenic berturut-turut adalah 80,34 dan 61,17 , sedangkan pada abses hati amoebic adalah sekitar 40,79 dan 44. Untuk natrium, kalium dan klorida pada kedua jenis hampir sama yaitu sekitar 135,59, 2,8 $\pm 0,7,98,67$ berturut-turut. Semua dianalisis menggunakan metode t-test atau Manwhitney dan didapatkan tidak ada perbedaan signifikan pada semua variabel kecuali kalium didapatkan $p<0,05$ yaitu 0,022 . Pemeriksaan USG yang dilihat adalah jumlah lesi, letak lobus dan diameter abses yang terbesar. Pada kedua jenis ditemukan banyak single lesi $(75,8 \%)$ yang terletak pada lobus kanan $(79,3 \%)$, sedangkan untuk rata-rata diameter terbesar keduanya berkisar 9,6 $\pm 3,25 \mathrm{~cm}$. semua dianalisis menggunakan chi-square dan T-test dengan hasil tidak terdapat perbedaan signifikan pada semua variable karena $p>0,05$.

Berdasarkan pilihan obat yang dipakai, seluruh pasien (100\%) menggunakan antibiotika. Antibiotika yang dipakai secara empiris adalah kombinasi metronidazole dan cephalosporin generasi ke-tiga. Metronidazole diberikan pada seluruh pasien abses hati, baik amoebic maupun pyogenic, sedangkan pemberian cephalosporin generiasi ketiga yaitu ceftriaxone merupakan pilihan yang paling banyak digunakan pada $51,7 \%$ pasien abses hati amoebic dan $48,3 \%$ pasien abses hati pyogenic. Selain metronidazole dan ceftriaxone obat pilihan yang dipakai adalah ciprofloxacin, levofloxacin, cefotaxime, dan cefixime. Di samping pemberian medikamentosa juga dilakukan drainase percutaneous atau operasi. Pada pasien abses hati amoebic didapatkan 65,6\% pasien dengan drainase percutaneous, dan $17,2 \%$ pasien dengan operasi. Sedangkan pada abses hati pyogenic diketahui; $34,5 \%$ dengan terapi drainage percutaneous, $31 \%$ dengan terapi dengan operasi. Berdasarkan data yang didapat pada hasil penelitian, data dianalisis menggunakan metode Chi-square 
karena variabel merupakan bentuk nominal, dan hasil analisis adalah tidak terdapat perbedaan yang signifikan pada kedua jenis abses. Hasil analisis Asymp. Sig adalah 0,061 yang berarti $p>0,05$.

Tabel 2. Manifestasi klinis pada pasien abses hati

\begin{tabular}{|c|c|c|c|c|}
\hline \multirow[b]{2}{*}{ Parameter } & \multicolumn{2}{|c|}{ Jenis Abses } & \multirow{2}{*}{$\begin{array}{c}\text { Total } \\
(\%) \\
n=58\end{array}$} & \multirow[b]{2}{*}{$\mathbf{p}$} \\
\hline & $\begin{array}{c}\text { Amoebic } \\
n=29\end{array}$ & $\begin{array}{c}\text { Pyogenic } \\
n=29\end{array}$ & & \\
\hline \multicolumn{5}{|l|}{ Gejala } \\
\hline Demam & $79,3 \%$ & $58,6 \%$ & $69 \%$ & 0,089 \\
\hline Mual & $65,2 \%$ & $70,0 \%$ & $50 \%$ & 0,793 \\
\hline Muntah & $34,7 \%$ & $30,0 \%$ & $24,13 \%$ & 0,539 \\
\hline Nyeri RUQ & $93,1 \%$ & $93,1 \%$ & $93,1 \%$ & 1,000 \\
\hline Ikterus & $62 \%$ & $51,7 \%$ & $56,8 \%$ & 0,426 \\
\hline Hepatomegaly & $69 \%$ & $72,4 \%$ & $70,6 \%$ & 0,773 \\
\hline $\begin{array}{l}\text { Pemeriksaan } \\
\text { Laboratorium }\end{array}$ & $\begin{array}{r}\text { Mean/ } \\
\text { Median } \\
\pm S D\end{array}$ & $\begin{array}{r}\text { Mean/ } \\
\text { Median } \\
\pm S D\end{array}$ & $\begin{array}{r}\text { Mean/ } \\
\text { Median } \\
\pm S D\end{array}$ & \\
\hline $\mathrm{Hb}$ & $\begin{array}{r}10,56 \pm \\
2,46\end{array}$ & $\begin{array}{r}10,56 \pm 2 \\
07\end{array}$ & $\begin{array}{r}10,56 \pm 2 \\
25\end{array}$ & 0,214 \\
\hline Leukosit & $\begin{array}{r}18.415 \\
\pm 6.982\end{array}$ & $\begin{array}{r}16.971 \pm \\
6.816\end{array}$ & $\begin{array}{r}17.693 \pm \\
6.877\end{array}$ & 0,687 \\
\hline Albumin & $\begin{array}{l}2,9 \pm \\
0,53\end{array}$ & $\begin{array}{l}2,6 \pm \\
0,63\end{array}$ & $\begin{array}{r}2,7 \pm \\
.0,6\end{array}$ & 0,674 \\
\hline Bilirubin Direk & 1,48 & 2,85 & 2,14 & 0,365 \\
\hline Bilirubik Total & 2,98 & 3,75 & 3,30 & 0,762 \\
\hline SGOT & 40,79 & 80,34 & 60,57 & 0,104 \\
\hline SGPT & 44,00 & 61,17 & 52,59 & 0,913 \\
\hline $\mathrm{Na}$ & 135,89 & 135,29 & 135,59 & 0,737 \\
\hline $\mathrm{K}$ & $\begin{array}{r}4,02 \pm \\
0,51\end{array}$ & $\begin{array}{r}3,73 \pm \\
0,82\end{array}$ & $\begin{array}{r}3,8 \pm \\
0,7\end{array}$ & 0,022 \\
\hline $\mathrm{Cl}$ & 99,97 & 97,47 & 98,67 & 0,793 \\
\hline \multicolumn{4}{|l|}{ Pemeriksaan } & \\
\hline Jumlah lesi & & & & 0,539 \\
\hline -Single & $72,4 \%$ & $79,4 \%$ & $75,8 \%$ & \\
\hline -Multiple & $27,6 \%$ & $20,6 \%$ & $24,2 \%$ & \\
\hline Lobus & & & & 0,431 \\
\hline -Kanan & $86,3 \%$ & $72,4 \%$ & $79,3 \%$ & \\
\hline -Kiri & $10,3 \%$ & $20,7 \%$ & $15,5 \%$ & \\
\hline -Kedua Lobus & $3,4 \%$ & $6,9 \%$ & $5,2 \%$ & \\
\hline Diameter & $\begin{array}{c}10,08 \pm \\
3,33\end{array}$ & $\begin{array}{c}9,19 \pm \\
3,17\end{array}$ & $\begin{array}{l}9,6 \pm \\
3,25\end{array}$ & 0,66 \\
\hline
\end{tabular}

Komplikasi terjadi lebih banyak pada pasien abses hati pyogenic $(68,9 \%)$ yang mengalami komplikasi daripada abses hati amoebic (44,8\%) yang dapat berupa empyema, efusi pleura, perforasi, sepsis, dan lain-lain. Berdasarkan data yang didapat komplikasi yang paling banyak terjadi adalah efusi pleura dan sepsis pada masing-masing jenis abses. Pada abses hati amoebic efusi pleura terjadi pada 9 pasien dan sepsis pada 8 pasien sedangkan pada abses hati pyogenic efusi pleura ditemukan pada 11 pasien dan sepsis pada 10 pasien. Berdasarkan data yang didapat pada penelitian dianalisis menggunakan metode Chi-square dengan hasil tidak terdapat perbedaan yang signifikan antara kedua jenis abses tersebut. Hasil analisis Asymp. Sig adalah 0,063 yang berarti $p>0,05$ dengan arti Ho ditolak.

Outcome pada penelitian ini terdiri dari LOS (Length of Stay) dan angka mortalitas. Length of Stay (LOS) dari pasien abses hati dihitung dari hari pertama pasien masuk ke rumah sakit hingga hari terakhir pasien berada di rumah sakit dan data menunjukkan rata-rata 15 hari $(S D= \pm 7)$ dengan hasil analisis $p>$ 0,05 (Asymp. Sig = 0,518). Rata-rata LOS dari pasien abses hati amoebic 14 hari $(\mathrm{Sd} .= \pm 7)$ sedangkan pada abses hari pyogenic menunjukkan angka 16 hari $(\mathrm{Sd}=$ \pm 7 ). Angka mortalitas berdasarkan data yang didapat diketahui bahwa dari 58 pasien, terdapat 4 pasien $(6,9 \%)$ yang meninggal dan 54 pasien hidup $(93,1 \%)$. Pasien yang meninggal tersebut berasal dari abses hati pyogenic, sedangkan

Pada abses hati amoebic tidak ada yang meninggal. Berdasarkan data yang diambil pada penelitian diketahui bahwa variabel merupakan variabel nominal dan dianalisis menggunakan metode Chi-Square dengan hasil terdapat perbedaan yang signifikan antara kedua jenis abses tersebut. Hasil analisis Asymp. Sig adalah 0,038 yang berarti $p<0,05$ dengan arti Ho diterima.

\section{PEMBAHASAN}

Pada penelitian ini didapatkan data bahwa pada abses hati didapatkan hasil mayoritas laki-laki dengan persentase lebih dari $85 \%$ pada kedua jenis. Pada abses hati amoebic didapatkan angka lebih tinggi yaitu $89,6 \%$ daripada pyogenic dengan angka $86,2 \%$. Hal ini dianalisis menggunakan Chi-square karena variabel 
nominal dan didapatkan hasil tidak terdapat perbedaan signifikan (Asymp. Sig. $=0,687, p>0,05$ ) pada kedua jenis tersebut. Menurut Ghosh et al pada penelitian di India pada tahun 2014, perbandingan rasio penderita laki-laki dan wanita adalah $13: 1 .^{12}$ Berdasarkan data yang didapat, diketahui bahwa rerata umur pasien abses hati amoebic adalah $42 \pm 17$ tahun, lebih muda daripada abses hati pyogenic yaitu sekitar $45 \pm 18$ tahun. Umur ditemukan lebih muda pada abses hati amoebic karena riwayat penyakit dahulu mayoritas adalah alkohol, sedangkan pada abses hati pyogenic lebih banyak riwayat berupa penyakit kronis seperti diabetes atau hipertensi. Umur dianalisis menggunakan uji t-test dan didapatkan bahwa $p>0,05$ (Asymp. Sig. $=0,516$ ) sehingga tidak didapatkan perbedaan signifikan pada variabel ini. Pada penelitian oleh Neill et al (2019) di Inggris juga didapatkan bahwa umur didapatkan lebih muda pada abses hati amoebic (median $=41$ tahun) dari pada abses hati pyogenic (median $=68$ tahun). ${ }^{13}$ Berdasarkan penelitian secara deskriptif didapatkan dominasi tingkat Pendidikan pada kedua jenis abses adalah pada tamat SLTA. Pekerjaan pada kedua jenis abses didominasi oleh pegawai swasta. Di India berdasarkan penelitian oleh Das et al (2015) didapatkan bahwa sekitar $82 \%$ pasien abses hati merupakan dalam golongan socioeconomi status rendah, dan $18 \%$ lainnya termasuk dalam middle-high socioeconomic status. ${ }^{14}$ Berdasarkan data yang didapat, jika dibandingan pada kedua jenis abses, riwayat penyakit dahulu lebih banyak terdapat pada abses hati pyogenic daripada amoebic. Pada abses hati amoebic riwayat yang paling banyak adalah alkohol sebesar $23,4 \%$, diikuti dengan hipertensi dan merokok sebesar $15,3 \%$. Sedangkan pada abses hati pyogenic yang terbanyak adalah pada diabetes melitus dan hipertensi yaitu sebesar 16,7\% dan alkohol mengikuti dengan 10,5\%. Menurut suatu penelitian di Inggris, pada abses hati amoebic lebih banyak ditemukan pasien yang menderita diabetes melitus $(33,3 \%) .^{13}$ Pada abses hati pyogenic lebih banyak ditemukan pasien riwayat diabetes mencapai 2 kali lipat $(60 \%)$ dari pasien abses hati amoebic. ${ }^{14}$ Data tersebut di analisis menggunakan metode Chi-Square karena variabel nominal sehingga didapatkan hasil tidak terdapat perbedaan signifikan pada kedua jenis tersebut (Asymp. Sig=0.056, p>0,05).

Gejala yang terdapat pada pasien abses hati yang akan dianalisis adalah demam, mual, muntah, nyeri Right Upper Quadran, ikterus, dan hepatomegaly. Berdasarkan data yang didapat, diketahui bahwa nyeri right upper quadran merupakan keluhan yang paling banyak ditemukan pada kedua jenis abses, yaitu bisa mencapai $93,1 \%$ dimana hal ini seimbang ditemukan pada kedua jenis. Dikatakan pada suatu penelitian di India bahwa nyeri abdomen ditemukan pada hampir seluruh penderita abses hati yaitu sekitar $99 \% .^{12}$ Data kemudian dianalisis menggunakan Chi-square dan didapatkan hasil bahw tidak terdapat perbedaan signifikan papda kedua jenis abses tersebut karena $p>0,05$ (Asymp. Sig. = 1). Hepatomegaly merupakan tanda kedua yang paling sering ditemukan pada pemeriksaan pasien abses hati. Berdasarkan data, dapat diketahui hampir $71 \%$ pasien abses hati mengalami hepatomegaly dan lebih banyak ditemukan pada pasien abses hati pyogenic. Berbeda dengan penelitian ini, pada penelitian di India hepatomegaly lebih sering ditemukan pada pasien abses hati amoebic (72.7\%) dari pada pyogenic $(66,6 \%) .{ }^{14} \mathrm{Hal}$ ini dianalisis menggunakan metode ChiSquare dan didapatkan bahwa tidak terdapat perbedaan signifikan pada kedua jenis abses karena p>0,05 (Asymp. Sig. = 0,773). Berdasarkan data yang didapat, diketahui bahwa demam merupakan gejala yang timbul pada kedua jenis abses hati sebesar $69 \%$. Pada abses hati amoebic (79,3\%) gejala ini timbul lebih banyak daripada abses hati pyogenic (58,6\%). Pada penelitian yang dilakukan oleh Das et al di India (2015) persentase pasien yang mengalami keluhan demam pada abses hati amoebic $(88,18 \%)$ dan pyogenic (87\%) menggambarkan angka yang hampir sama. ${ }^{14}$ Setelah di analisis menggunakan Chi-square hasilnya adalah tidak terdapat perbedaan yang signifikan pada variabel tersebut. Pada data yang didapat, diketahui bahwa mual lebih sering ditemukan pada kedua abses dari pada muntah, dan pada abses hati amoebic lebih banyak keluhan mual muntah daripada pyogenic. Dikatakan bahwa pada penelitian di India, keluhan mual muntah didapatkan pada $54 \%$ $(n=108)$ pasien abses hati secara umum. ${ }^{12}$ Hasil 
analisis menggunakan metode Chi-square didapatkan bahwa tidak terdapat perbedaan yang signifikan karena $p>0,05$ (Asymp. Sig. mual $=0,793$, muntah= 0,539). Ikterus lebih banyak ditemukan pada abses hati amoebic sebesar $62 \%$, sedangkan pada abses hati pyogenic hanya sekitar $51,7 \%$. Pengukuran ikterus menggunakan metode Jendrassik \& Grof dan menggunakan batas normal bilirubin total $0,2-1 \mathrm{mg} / \mathrm{dl}$, jika melebihi batas normal makan akan disebut hiperbilirubinemia dan memberi tanda ikterus. Ikterus ditemukan pada pemeriksaan fisik pada mata atau kulit. ${ }^{15}$ Menurut Ghosh et al (2014), di India adanya keluhan ikterus hanya terdapat pada $26 \%$ pasien abses hati secara umum. ${ }^{12}$ Ikterus ditemukan pada pasien abses hati (terutama amoebic) maka hal tersebut dapat menjadi pertanda penyakit berat. ${ }^{16}$ Setelah data dianalisis menggunakan metode Chisquare ternyata tidak didapatkan perbedaan yang berarti pada kedua jenis abses karena $p>0,05$ (Asymp. Sig. =0,426).

Pemeriksaan laboratorium akan dianalisis menggunakan uji t-test, jika data terdistribusi normal, atau Man-Whitney tes (Non-Parametric), jika data tidak terdistribusi normal. Variabel yang akan dibahas antara lain: $\mathrm{Hb}$, leukosit, albumin, bilirubin direk, bilirubin total, SGOT, SGPT, natrium, kalium, klorida. Berdasarkan data dapat diketahui bahwa $\mathrm{Hb}$ pada kedua jenis abses menunjukkan rerata yang sama yaitu sekitar 10,56 $\pm 2,25 \mathrm{mg} / \mathrm{dl}$. Di India, rerata dari kadar $\mathrm{Hb}$ abses hati adalah 11,2 $\pm 1,9 \mathrm{mg} / \mathrm{dL}$, dan dari range tersebut sekitar $40 \%$ berada di luar dari range tersebut. $^{12}$ Setelah dianalisis menggunakan uji t-test, ternyata data terdistribusi normal dan didapatkan hasil $p>0,05$ sehingga tidak terdapat perbedaan signifikan antara abses hati amoebic dan pyogenic terhadap $\mathrm{Hb}$. Berdasarkan hasil penelitian yang didapat diketahui bahwa leukosit lebih tinggi pada abses hati amoebic dari pada pyogenic. Pada abses hati amoebic rerata mencapai $18.415 \pm 6.982 \mu / l$, sedangkan pada abses

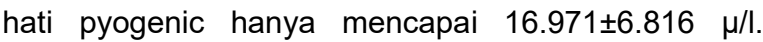
Leukositosis $(>10.000 \mu / \mathrm{l})$ lebih banyak terdapat pada abses hati pyogenic, dikatakan pada suatu penelitian di India hampir seluruh pasien abses hati pyogenic mengalami leukositosis. ${ }^{14}$ Hasil analisis menggunakan uji t-test, karena data terdistribusi normal, didapatkan hasil $p>0,05$ yang berarti tidak terdapat perbedaan signifikan terhadap kedua jenis abses hati. Albumin berdasarkan data yang diambil dapat diketahui bahwa lebih tinggi kadarnya pada abses hati amoebic dari pada abses hati pyogenic. Rerata kadar albumin pada abses hati amoebic adalah 2,9 $\pm 0,53 \mathrm{~g} / \mathrm{dL}$, sedangkan pada abses hati pyogenic adalah $2,6 \pm 0,63 \mathrm{~g} / \mathrm{dL}$. Pada abses hati pyogenic didapatkan hasil lebih rendah dikarenakan adanya riwayat penyakit dahulu yang mayoritas berupa penyakit kronis seperti diabetes melitus atau hipertensi sehingga kadar albumin turun terlebih dahulu pada abses hati pyogenic dibandingkan amoebic. Data ini dianalisis menggunakan uji t-test karena data terdistribusi normal, dan hasil yang didapat adalah tidak terdapat perbedaan signifikan pada kedua jenis abses. Di India, rerata kadar albumin adalah 3,0 $\pm 0,56 \mathrm{~g} / \mathrm{dL} .{ }^{12}$ Adanya hypoalbuminemia maka bisa menjadikan prognosis pasien menjadi buruk. ${ }^{16}$ Berdasarkan diketahui bahwa pada bilirubin direk and bilirubin total nilai terlihat lebih tinggi pada abses hati pyogenic daripada amoebic. Median dari kedua jenis abses hati adalah sekitar 3,3 $\mathrm{mg} / \mathrm{dL}$. Hal ini dapat terjadi karena kebanyakan penyebab abses hati pyogenic adalah bakteri dari jalur descending, yaitu dari saluran pencernaan atas yang turun dan memasuki hepar dari vena porta. Bakteri yang menginfeksi liver akan menyebabkan necrotizing gangrene dengan gas dalam jumlah besar sehingga dapat menyebabkan kerusakan fungsi dari liver yang secara tidak langsung menaikkan kadar bilirubin. ${ }^{17}$ Sedangkan pada abses hati amoebic, bakteri datang dari seluran pencernaan bawah yang naik ke atas, jalur ascending, dan pada tubuh manausia didapatkan suatu pertahanan alami terhadap amoeba pada saluran pencernaan manusia sehingga kerusakan yang disebabkan oleh amoeba bisa lebih ringan dibandingkan yang disebabkan oleh bakteri pyogenic. ${ }^{18}$ Menurut Das et al (2015) di India jumlah pasien dengan bilirubin total diatas $0,1 \mathrm{mg} / \mathrm{dL}$ lebih banyak ditemukan pada abses hati pyogenic, hingga hampir mencapai $27 \% .^{14}$ Setelah dianalisis menggunakan uji Man-Whitney didapatkan hasil tidak terdapat perbedaan signifikan terhadap kedua variabel tersebut. SGOT/AST dan SGPT/ALT merupakan enzim pada hati yang dipakai untuk mengukur fungsi hati, dan hal ini lebih tinggi kadarnya pada abses hati pyogenic dibandingkan dengan amoebic. Nilai median 
SGOT dan SGPT pada abses hati pyogenic lebih tinggi dari pada amoebic, pada pyogenic yaitu sekitar 80,34 U/L dan 61,17 U/L secara berturut-turut. Pada abses hati amoebic kadar SGOT adalah 40,79 U/L dan kadar SGPT adalah $44 \mathrm{U} / \mathrm{L}$. Hal ini dapat terjadi karena infeksi yang disebabkan oleh bakteri pyogenic dapat menyebabkan kerusakan yang lebih massive, sehingga hepar mengeluarkan enzim dalam jumlah lebih besar dibandingkan dengan abses hati amoebic. Sel neutrophil yang berasal dari intestine dapat menghambat amoebic lebih terlebih dahulu sehingga kerusakan yang disebabkan oleh amoebic bisa lebih ringan dari pyogenic. ${ }^{18}$ Menurut Das et al (2015) pada penelitian di India, kenaikan SGOT dan SGPT lebih banyak ditemukan pada abses hati pyogenic. ${ }^{14}$ Variabel ini merupakan data dengan distribusi tidak normal sehingga dianalisis menggunakan metode Man-Whitney dan didapatkan hasil bahwa tidak terdapat perbedaan signifikan pada kedua variabel karena $p>0,05$.

Hasil pemeriksaan USG yang akan dianalisis adalah lokasi abses (letak lobus), jumlah lesi, dan diameter abses hati. Letak abses dibagi menjadi pada lobus kanan, kiri, atau pada kedua lobus. Pada lobus kanan terdapat segmen V, VI, VII, dan VIII, sedangkan pada lobus kiri terdapat segmen I, II, III, dan IV (IVa dan IVb). Sekitar $79,3 \%$ letak abses adalah pada lobus kanan di kedua jenis abses. Hal ini dapat terjadi karena struktur anatomi hepar lebih besar lobus kanan daripada lobus kiri, sehingga vaskularisasi yang ada didalam lobus lebih banyak pada lobus kanan daripada kiri. Keadaan tersebut menaikkan kemungkinan bakteri atau amoeba untuk memasuki hepar lebih banyak pada lobus kanan daripada lobus kiri melewati vaskularisasi yang ada pada hepar. Menurut suatu penelitian di India, sekitar $>80 \%$ kedua jenis pasien abses hati terletak pada lobus kanan. ${ }^{14}$ Setelah dianalisis menggunakan metode Chi-square didapat bahwa tidak terdapat perbedaan yang signifikan terhadap kedua jenis tersebut. Jumlah lesi pada abses hati adalah single atau multiple dan pada kedua tipe abses hati menunjukkan hasil lebih banyak pada single abses. Pada abses hati pyogenic yang terkena lesi single menunjukkan angka lebih banyak daripada amoebic yaitu sekitar 79,3\% sedangkan pada amoebic hanya menunjukkan angka $72,4 \%$.
Menurut Ghosh et al pada tahun 2015, di India sekitar $11 \%$ hasil USG terdapat $\leq 3$ abses hati dan $23,5 \%$ terdapat $>3$ abses hati. $^{12}$ Setelah dianalisis menggunakan uji Chi-square, didapatkan hasil tidak terdapat perbedaan yang signifikan antara abses hati amoebic dan pyogenic. Besar diameter dari abses hati diukur menggunakan pemeriksaan USG dalam satuan cm dan diambil angka yang paling besar dari hasil USG. Rerata diameter dari kedua jenis abses hati adalah 9,6 $\pm 3,25 \mathrm{~cm}$. Hal ini dapat terjadi karena sifat amoeba yang lebih dominan untuk menginvasi pada berkelompok di satu tempat, daripada seperti bakteri yang hidup tidak berkelompok. Pada infeksi oleh bakteri diameter cenderung lebih kecil akan tetapi tersebar di beberapa tempat. Pada penelitian yang dilakukan oleh Takano et al (2017) pasien dengan riwayat diabetes akan mempngaruhi ukuran abses yang terjadi, terutama hal ini banyak ditemukan pada abses hati pyogenic. ${ }^{19}$ Data dianalisis menggunakan uji t-test karena distribusi data normal, sehingga didapatkan hasil $p>0,05$ sehingga tidak didapatkan perbedaan yang signifikan pada besar diameter kedua jenis abses.

Pilihan medikamentosa pada kedua jenis hati paling banyak adalah menggunakan metronidazole kombinasi dengan cephalosporin generasi ketiga. Pilihan cephalosporin generasi ketiga dari medikamentosa yang paling banyak digunakan adalah ceftriaxone. Di Amerika untuk abses hati amoebic pilihan utama tetap metronidazole, akan tetapi bisa dikombinasikan dengan luminal agents untuk menghindari terjadinya kolonisasi pada intestinal. ${ }^{16}$ Abses hati pyogenic diterapi menggunakan cephalosporin generasi ke-3 dikombinasikan dengan metronidazole. ${ }^{16}$ Kedua obat tersebut adalah medika mentosa yang paling sering dikombinasi untuk jadi terapi pasien abses hati. Hal ini dikarenakan secara klinis sulit untuk membedakan antara abses hati amoebic dan pyogenic saat pasien pertama kali masuk rumah sakit, dan masih jarang dilakukan pemeriksaan kultur pada pus, darah, atau jaringan yang memberikan hasil jenis bakteri dan jenis antibiotik yang sensitif untuk bakteri tersebut. Selain kedua pilihan obat itu juga ada ciprofloxacin, levofloxacin, cefotaxime, dan cefixime, akan tetapi obat-obat tersebut jarang digunakan untuk terapi dari 
abses hati di RSUD Dr. Soetomo. Seluruh pasien dilakukan pemberian medikamentosa akan tetapi yang berbeda adalah pemberian drainase atau dilakukannya operasi. Pada abses hati amoebic paling banyak ditemukan terapi menggunakan drainase percutaneous sekitar $65,6 \%$, sedangkan pada abses hati pyogenic terapi menggunakan drainase percutaneous mempunyai jumlah yang sama yaitu sekitar 34,5\%. Di RSUD Dr. Soetomo lebih banyak digunakan drainage karena aspirasi bisa dilakukan dengan lebih mudah. Aspirasi dilakukan dengan cara mengeluarkan cairan yang berada pada jaringan lalu pada saat yang sama dapat mengumpulkan cairan tersebut. $^{20}$ Operasi dilakukan jika metode lain sudah tidak ada yang efektif dan biasanya terjadi komplikasi. Dikatakan pada suatu penelitian di India, 100\% pasien abses hati amoebic menggunakan percutaneous drainage dengan angka kesuksesan mencapai $67 \% .{ }^{14}$

Komplikasi pada pasien abses hati lebih banyak terjadi pada abses hati pyogenic dari pada amoebic. Sekitar $69 \%$ pasien abses hati pyogenic mengalami komplikasi. Di China, sekitar 10,8\% pasien abses hati mengalami komplikasi. ${ }^{21} \mathrm{Hal}$ ini dapat terjadi karena sifat dari infeksi bakteri untuk menyebar lewat pembuluh darah lebih besar daripada amoeba, kebanyakan dari infeksi amoeba hanya terbatas pada intestinal. Manifestasi klinis yang ditimbulkan oleh abses hati pyogenic juga lebih banyak sistemik, sehingga tingkat keparahan juga dapat lebih tinggi daripada amoebik. Komplikasi dapat berupa empyema, efusi pleura, perforasi, sepsis, dan lain-lain. Diketahui bahwa pada kedua jenis abses hati didapatkan komplikasi terbanyak adalah efusi pleura dan sepsis. Di Amerika, rupture abses lebih banyak mengenai ruang dada daripada peritoneum, sehingga sering menyebabkan terjadinya empyema. ${ }^{16}$ Dan jika mengenai pericardium maka akan menjadi penyebab mortalitas. ${ }^{16}$ Di China, pasien mengalami komplikasi sepsis sekitar $1,1 \%$ dan acute respiratory failure sekitar $3,3 \%$. $^{21}$

Outcome pada pasien abses hati yang akan dianalisis adalah mortalitas dan LOS (Length of Stay). LOS dari pasien abses hati dihitung dari hari pertama pasien masuk ke rumah sakit hingga hari terakhir pasien berada di rumah sakit dan data menunjukkan rerata 15 hari $(S D= \pm 7$ hari). Di India, rerata LOS adalah sekitar 7 hari dengan range 3 hingga 11 hari. $^{12}$ Di China, total LOS adalah sekitar 20 hingga 23 hari. $^{21}$ $\mathrm{Hal}$ ini berbeda dikarenakan banyak pasien abses hati yang melakukan operasi sehingga dapat memperpanjang rerata LOS dari pasien, selain itu juga dapat disebabkan banyak juga pasien yang mengeluh mual muntah sehingga hal itu dapat memperpanjang waktu perawat dari pasien. Berdasarkan data diketahui bahwa pada abses hati pyogenic 13,7\% yang meninggal sedangkan pada amoebic tidak didapatkan pasien meninggal. Maka jika dianalisis menggunakan Chi-square maka akan didapatkan hasil terdapat perbedaan yang signifikan pada mortalitas dari kedua jenis abses hati karena $p<0,05$ (Asymp. Sig $=0,038)$. Di China, angka mortalitas dari abses hati pyogenic adalah sekitar $8,2 \% .{ }^{21} \mathrm{Di}$ India, mortality rate dari abses hati secara umum adalah sekitar 2,5\%, akan tetapi meningkat seiring terjadinya komplikasi dan dapat mencapai $15 \% .^{12}$ Hal ini dapat terjadi karena abses hati pyogenic lebih mengarah ke outcome yang lebih buruk dari pada abses hati amoebic, dapat terjadi komplikasi lebih banyak dan dalam keadaan yang lebih parah. Selain komplikasi underlying disease juga dapat mempengaruhi tingkat keparahan penyakit tersebut.

\section{SIMPULAN}

Pada hasil pemeriksaan laboratorium $\mathrm{Hb}$ menunjukkan rerata yang hampir sama pada kedua jenis, leukosit dan albumin lebih tinggi pada amoebic, sedangkan bilirubin, SGOT dan SGPT lebih tinggi pada pyogenic. Hasil pemeriksaan USG didapatkan lebih banyak single abses pada lobus kanan di kedua jenis abses. Gambaran terapi pasien abses hati semua menggunakan antibiotik. Tidak ada perbedaan antara drainage percutaneous dengan operasi pada kedua kelompok. Komplikasi lebih banyak terjadi pada abses hati pyogenic, hal itu berupa efusi pleura dan sepsis. LOS pada kedua jenis abses tidak ada perbedaan akan tetapi angka mortalitas lebih tinggi pada abses hati pyogenic dari pada abses hati amoebic. Terdapat perbedaan profil pasien abses hati amoebic dan pyogenic pada karakteristik dan gambaran klinis, terutama pada angka mortalitas perbedaan dapat terbukti secara statistik. Penelitian selanjutnya disarankan untuk melakukan penelitian 
dengan pemeriksaan laboratorium kultur pada pus/darah/jaringan agar dapat mengetahui jenis bakteri, terutama pada abses hati pyogenic atau melakukan penelitian dengan periode waktu yang lebih panjang, sehingga didapatkan sampel yang lebih banyak dan hasil yang lebih akurat.

\section{DAFTAR PUSTAKA}

1. Misdraji J, Masia R. Liver and bile duct infections. Dalam: Kradin RL, editor (penyunting). Diagnostic pathology of infectious disease: Elsevier Health Sciences; 2010. hlm. 255.

2. Su YJ, Lai YC, Lin YC, Yeh YH. Treatment and prognosis of pyogenic liver abscess. International Journal of Emergency Medicine. 2010 Dec; 3(4): 381.

3. Frey C, Verlenden W. Management of liver abscess. Am J Surg. 1980;140(1). hlm. 53-9.

4. Ayles HM, Bailey SL. Hepatic abscesses and cysts. Dalam: Friedman L, Martin P, editor (penyunting). Handbook of Liver Disease: Elsevier; 2017. hlm. 395-412.

5. Beal E, Black S. Shackelford's Surgery of the Alimentary. Edisi ke-8: Elsevier; 2019. hlm. 143045.

6. Kaplan GG, Gregson DB, Laupland KB. Population-based study of the epidemiology of and the risk factors for pyogenic liver abscess. Clinical Gastroenterology and Hepatology. 2004 Nov 1;2(11):1032-8

7. Abbas MT, Khan FY, Muhsin SA, Al-Dehwe B, Abukamar M, Elzouki AN. Epidemiology, clinical features and outcome of liver abscess: a single reference center experience in Qatar. Oman Medical Journal. 2014 Jul;29(4):260.

8. Davis J, McDonald M. Pyogenic liver abscess. 2018 (diakses 21 April 2019). Tersedia dari: https://www.uptodate.com/contents/pyogenic-liverabscess

9. Pilcher JM. Liver Infections and inflammations. Dalam: Allan P, Baxter G, Weston M, editor (penyunting). Clinical Ultrasound. Edinburgh: Churchill Livingstone; 2011. hlm.120-37.
10. Walsh JA. Problems in recognition and diagnosis of amebiasis: Estimation of the global magnitude of morbidity and mortality. Reviews of infectious diseases. 1986 Mar 1;8(2):228-38.

11. Gandahusada S. Important protozoan parasites in Indonesia. Indonesian Bulletin of Health Research. 1989;17(2):222732

12. Ghosh S, Sharma S, Gadpayle AK, Gupta HK, Mahajan RK, Sahoo R, Kumar N. Clinical, laboratory, and management profile in patients of liver abscess from northern India. Journal of Tropical Medicine. 2014; 2014:142382.

13. Neill L, Edwards F, Collin SM, Harrington D, Wakerley D, Rao GG, McGregor AC. Clinical characteristics and treatment outcomes in a cohort of patients with pyogenic and amoebic liver abscess. BMC infectious diseases. 2019 Dec $1 ; 19(1): 490$.

14. Das A, Jha AK, Chowdhury F, Biswas MR, Prasad SK, Chattopadhyay S. Clinicopathological study and management of liver abscess in a tertiary care center. Journal of Natural Science, Biology, And Medicine. 2015 Jan;6(1):71.

15. Scully C. Scully's Medical Problems in Dentistry. Edisi ke-7: USA: Elsevier Health Sciences (EBook); 2015.

16. Kurland JE, Brann OS. Pyogenic and amebic liver abscesses. Current Gastroenterology Reports. 2004 Aug 1;6(4):273.

17. Minemura M, Tajiri K, Shimizu Y. Liver involvement in systemic infection. World J Hepatol 6.2014: 63242.

18. Stanley Jr SL. Amoebiasis. The lancet. 2003 Mar 22;361(9362):1025-34.

19. Takano Y, Hayashi M, Niiya F, Nakanishi T, Hanamura S, Asonuma K, Yamamura E, Gomi K, Kuroki Y, Maruoka N, Inoue K. Life-threatening emphysematous liver abscess associated with poorly controlled diabetes mellitus: a case report. BMC Research Notes. 2017 Dec;10(1):1-4.

20. Rutherford EE, Stedman B, Breen DJ. Interventional ultrasound in the abdomen. Dalam: Allan P, Baxter G, Weston M. Clinical Ultrasound. Edinburg: Churchill Livingstone; 2011.hlm. 847864. 
21. Chen $Y C$, Lin $C H$, Chang SN, Shi ZY Epidemiology and clinical outcome of pyogenic liver abscess: An analysis from the National Health
Insurance Research Database of Taiwan, 2000-2011. Journal of Microbiology, Immunology and Infection. 2016 Oct 1;49(5):646-53. 